\title{
The Status and Future Development Direction of the Water Industry in Gyeongsangnam-do Province
}

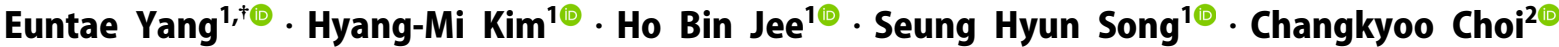 \\ 'Department of Marine Environmental Engineering, Gyeongsang Nation University \\ ${ }^{2}$ Water Convergence Research Team, Korea Water Cluster, Korea Environment Corporation
}

(Received December 29, 2020; Revised March 25, 2021; Accepted April 7, 2021)

Objectives: The status of the future development direction of the water industry in Gyeongsangnam-do Province have been explored.

Methods: The status of the global and domestic water industry and the local water industry in Gyeongsangnamdo was examined through a simple survey analysis and the utilization of related-statistical data and databases. Also, the water industry development strategies of Gyeongsangnam-do were investigated by considering the status and the regional and industrial-based characteristics of Gyeongsangnam-do.

Results and Discussion: The global water industry and markets have constantly been grown. The growth of the global water market was forecasted to slow down a bit due to the recent COVID-19 epidemic. On the other hand, it has promoted investment in new areas such as monitoring viruses in sewage. Although the infrastructure of the domestic water industry is well established, there are several problems such as profit structure by simple facility investment, and the poor financial condition and the lack of technical skills of the water industry-related companies. The supply rate of water and sewage in Gyeongsangnam-do was shown lower than the national average due to many islands and mountainous areas. The number of water industry-related companies was found to be about 1300 and Gyeongsangnam-do has quite a large number of water industry-related companies compared to other provinces. By sector, manufacturing industries that produce water-related components such as valves and pumps accounted for more than $60 \%$. By scale based on the number of employees showed that "less than nine" accounted for more than $60 \%$. More than $86 \%$ out of the total number of local water-industry companies did not conduct research and development activities. Many companies suffer from difficulties to develop technologies and pioneer new markets owing to the financial burden and lack of professional manpower. To overcome these difficulties and promote the local water industry, strategies such as creating an environment for water industry promotion, establishing a corporate support system, strengthening domestic and foreign networks, and expanding the scale of the domestic market by creating a new water business and finding additional demand by utilizing local characteristics and industrial advantages.

Conclusions: Although there are various problems that need to be solved to develop the water industry in Gyeongsangnam-do Province, the Korean government is making efforts to develop the water industry these days. It is necessary to establish and implement effective development strategies and policies for promoting the local water industry in Gyeongsangnam-do Province.

Keywords: Gyeongsangnam-do, Water Industry Status, Development Direction. 


\title{
경상남도 물산업 현황 및 발전 방안
}

\author{
양은태 ${ }^{1+\oplus} \cdot$ 김향미 $^{1 \odot} \cdot$ 지호빈 $^{1 \odot} \cdot$ 송승현 $^{1 \odot} \cdot$ 최창규 $^{2 \odot}$ \\ ${ }^{1}$ 경상대학교 해양환경공학과 \\ 2한국환경공단 국가물산업클러스터 물융합연구부
}

목적: 경상남도의 물산업 현황과 발전 방안을 살펴보고자 한다.

방법: 전세계 물산업과 경상남도의 지역 물산업 현황을 통계자료 및 데이터베이스의 활용, 기업을 대상으로 한 설 문조사 등을 통하여 파악하였다. 그리고 이를 통해 파악된 현황과 경상남도의 산업 기반 및 지역적 특성 등이 고려 된 지역 물산업 발전 전략을 살펴보았다.

결과 및 토의: 세계 물시장은 지난 몇십 년 간 지속적으로 성장해 왔지만, 최근 코로나 대유행으로 인해 성장세가 다소 둔화될 것으로 전망되었다. 그러나 하수 내 바이러스 모니터링 등 새로운 분야에 대한 투자를 촉진시킨 측면 도 있다. 국내 물산업의 경우 인프라는 잘 갖추어졌지만, 단순한 시설투자에 의한 매출 발생 구조, 물기업의 영세 성과 기술력 부족 등의 문제점이 있는 것으로 드러났다. 경상남도 지역 물산업의 경우, 인프라와 관련된 상하수도 보급률은 도서산간지역이 많은 이유로 전국평균보다 낮지만, 물산업 관련 기업 수는 약 1300 여개가 있는 것으로 파악되어 타시도와 비교해 많은 편으로 나타났다. 업종별로는 밸브 및 펌프 같은 물산업 관련 부품을 생산하는 제 조업이 $60 \%$ 이상을 차지하였다. 규모에 따른 분포에서는 ‘종업원 9 인 이하’의 기업이 $60 \%$ 이상을 차지하는 것으 로 나타났다. 약 $86 \%$ 이상의 기업이 연구개발 활동을 하지 않는 것으로 파악되었다. 이는 많은 기업이 자금 부담 및 전문 인력 부족으로 인해 기업 자체적으로는 기술 개발 및 시장 개척에 어려움을 겪고 있는 현실을 보여준다. 이러한 현실을 극복하고 지역 물산업을 발전시키기 위해서는 지방정부를 중심으로 한 물산업 육성 환경조성, 기업 지원 체계 마련, 국내외 네트워크 강화 및 협력체계 구축, 지리적 특성과 산업적 장점을 활용한 물산업 육성, 추가 수요 발굴을 통한 내수시장 규모 확대 등의 전략이 필요하다.

결론 : 경상남도 지역 물산업 육성을 위해 해결해야하는 여러 문제점이 있다. 그러나 최근 정부가 본격적으로 물산 업 발전을 위해 노력을 하고 있다. 따라서 경상남도도 지역 물산업의 육성을 위해 실효성 있는 발전 전략 및 정책 을 수립하고 실천하는 것이 필요하다.

주제어 : 경상남도, 물산업 현황, 발전 방향

\section{1. 서론}

물은 현대 문명 사회를 지탱하기 위한 필수 자원이지만, 인 간이 사용 가능한 수자원은 지구 전체 수자원의 $0.26 \%$ 에 불과 하다. ${ }^{1)}$ 지구 전체 수자원 중 극히 일부의 양이지만, 지구의 물 순환 시스템(hydrologic cycle $\left.{ }^{1)}\right)$ 에 의해 지구 전체 생명체 가 사용할 수 있는 양의 물이 공급되었다. 하지만, 1900 년대 이후 급격한 도시화 및 산업화, 폭발적인 인구증가는 심각한 수질오염과 폭발적인 물 사용량 증가를 초래하였다. 또한, 기 후변화는 수자원의 지역적 불균형을 더욱 심화 시켜 더 이상 자연적인 물 순환 시스템에 의해 인류 문명을 유지하는데 필 요한 양의 물을 공급 받는 것은 어려워졌다. ${ }^{2)}$ 2020년 발간된
세계 물 개발 보고서에 따르면'3), 현재 약 16 억 명의 세계 인구 가 필요한 물을 얻기 위한 인프라의 부족으로 경제적 물부족 (economic water shortage)을 겪고 있으며, 2050년에는 세계 570 여개의 도시에 살고 있는 6.85 억 명의 사람들이 기후변화 에 따른 가용 수자원 감소로 고통받을 것으로 예상되었다. 따 라서, 지속가능한 가용수자원의 확보는 향후 인류 생존과 국 가 경쟁력 제고를 위해 반드시 필요하다.

현재 지속가능한 가용수자원 확보를 위해 전세계 많은 국가 들이 지속적으로 노력하고 있다. 이에 따라 물기술이 급격히 발전하였고, 물시장의 규모 역시 크게 성장하였다. ${ }^{4)}$ Global Water Intelligence (GWI)가 2017년 발간한 자료(Fig.1)에 의 하면 ${ }^{5}$, 글로벌 물시장은 2013년 이후 연평균 약 4.2\%씩 지속 

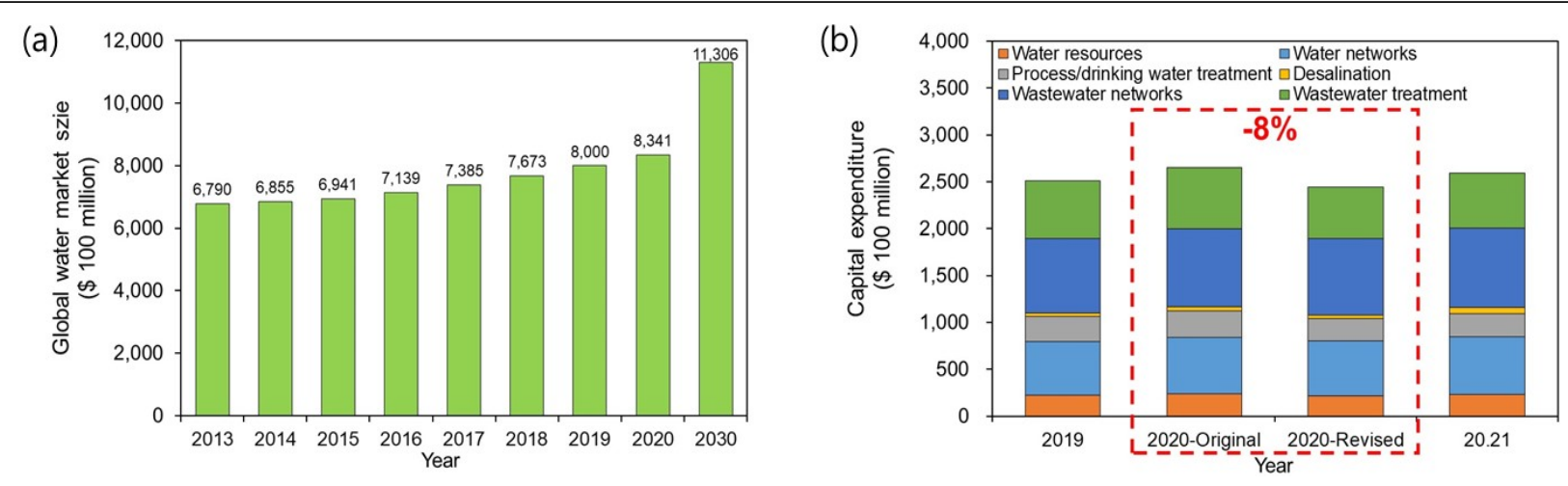

Fig. 1. (a) The growth trend in the global water market (source: Global Water Intelligence) ${ }^{5)}$, (b) adjusted investment forecast towards the global water market after COVID-19 pandemic (source: Global Water Intelligence, water industry trends issued by K-Water). ${ }^{13)}$

적으로 성장하여 2020 년에는 그 규모가 8,341 억 달러에 이를 것으로 예측되었다. 그리고 이러한 추세는 개발도상국의 지속 적인 인구증가 및 산업화로 인한 물 수요의 증가와 선진국의 노후화된 물 관련 인프라 교체, 환경 기준 강화 등의 이유로 형성된 새로운 시장 덕분에 앞으로도 지속될 전망이다. ${ }^{.)}$따라 서, 주요 물산업 선진국들은 이러한 물시장을 선점하기 위해 전략적인 접근을 하고 있다.) 대한민국 정부도 물시장의 중요 성을 인식하고 2019년 '제1차 물관리 기술 발전 및 물산업 진흥 기본계획’을 마련하였다. 그리고 이를 토대로 물관리 기 술에 대한 선진화, 해외 시장 진출 활성화 및 새로운 시장 개 척, 물산업 관련 전문 인력 양성과 일자리 창출, 물산업 진흥 을 위한 전략 체계 구축을 통해 물산업 선진국으로 도약하기 위해 노력하고 있다. ${ }^{8)}$ 또한 주요 지자체 역시 각 지역의 특성 및 인프라를 고려한 지역 물산업 발전 전략을 수립하여 향후 지역 발전을 견인할 새로운 성장동력 확보를 꾀하고 있다. ${ }^{8-10)}$ 경상남도의 경우도 경기도, 대구, 제주도와 같이 지역 물산업 육성에 적극적인 지자체보다는 다소 늦었지만, 지역 특성을 고려한 물산업 육성을 위한 계획 수립과 실행을 위한 노력을 기울이고 있다.

본 기술보고서는 경상남도의 물산업 현황에 대해서 살펴보 고, 향후 경상남도의 지속가능한 물관리 기술 확보와 물산업 육성을 위한 방안에 대해 살펴보고자 한다.

\section{2. 연구방법}

전세계 물시장 성장 추세 및 규모 자료는 국외 문헌 및 통계 자료 검색을 통해 확보되었다. 국내 물시장의 규모 및 현황은 환경부 물기술종합정보시스템 데이터베이스를 참고하였다. 경상남도의 물 관련 인프라 및 물산업 현황은 경상남도 빅데 이터허브포털의 통계자료, 환경부, 환경산업기술원, 낙동강유 역환경청, 국립환경과학원, 공공데이터포털의 보고서, 수자원 공사 물산업플랫폼 상의 통계자료를 활용하여 파악하였다.
Table 1. Scope of water industry-related companies in Gyeongsangnam-do province for this report.

\begin{tabular}{|c|c|}
\hline Major categories & Minor categories \\
\hline \multirow{3}{*}{ Manufacturing } & Bottled water production \\
\hline & Chemical production \\
\hline & Tap, valve, pump, etc. manufacturing \\
\hline \multirow{3}{*}{ Operation and purification } & Operation \\
\hline & Maintenance \\
\hline & Purification and cleaning \\
\hline Construction & Construction \\
\hline \multirow{2}{*}{$\begin{array}{c}\text { Design and engineering } \\
\text { service }\end{array}$} & Design and diagnostic consulting \\
\hline & Waterfront industries \\
\hline
\end{tabular}

경상남도의 물산업 관련 기업 현황은 수자원공사의 물산업 플랫폼시스템 상의 물산업 관련 기업 데이터베이스를 활용하 였다. ${ }^{11}$ 수자원 공사의 물산업플랫폼시스템의 물산업 관련 기 업 데이터베이스에서는 기업주소를 '경상남도'로 한정하여 검색한 결과로부터 경상남도 내의 기업 정보를 추출하였다. 데이터베이스를 통하여 확보된 기업리스트는 Table 1과 같이 4 개 업종으로 분류되었다.

위로부터 확보된 경상남도 물기업리스트는 각 기업이 보유 한 특허 조사와 설문조사를 실시하는데 활용되었다. 경상 남도 물기업이 보유한 특허조사는 특허데이터베이스인 윕스온 (WIPS ON)을 사용하였고, 출원인의 주소를 검색하는 방법으 로 이루어졌다. 그리고 각 시도의 특허는 물산업과 관련된 키 워드의 조합('상수’, ‘하수’, ‘폐수’, ‘물재이용’, ‘담수화', ‘수 처리')과 출원인의 주소를 검색하여 데이터를 확보하였다.

경상남도 물산업 관련 기업 대상 설문조사는 주소정보가 확 보된 경상남도 내의 총 66 개의 물산업 관련 기업을 대상으로 실시하였다. 설문지는 기업의 종업원수, 매출액, 수출여부, 향 후수출계획, 운영의 애로사항과 물산업 육성을 위해 필요한 사항에 대한 문항으로 이루어졌다. 운영의 애로사항과 물산업 육성을 위해 필요한 사항에 대한 문항은 복수 응답이 가능하 
도록 설정하였다.

\section{3. 결과 및 고찰}

\section{1. 글로벌 물산업 동향}

$\mathrm{OECD}$ 가 2012년 발간한 '환경 전망 2050' 보고서에 따르면, 2050 년 세계 인구는 현재보다 약 20 억 명이 증가한 100 억 명 에 육박할 것으로 예측되었다. 이로 인한 경제 규모는 약 4 배 정도 성장하며, 전세계 물 수요량은 약 $55 \%$ 가 증가할 것으로 전망되었다. ${ }^{12)}$ 이처럼 급격한 증가가 예상되는 물 수요량에 맞추어 물 인프라에 대한 투자 또한 꾸준히 증가할 것으로 예상된다. 2030년까지 물 인프라 시장은 세계 인프라 시장의 절반이상을 차지할 것으로 내다봤다. 물은 대표적인 공공재적 특성을 가진 자원이기 때문에 물산업은 각국 정부의 규제와 정책이 수요에 미치는 영향력이 아주 강하다. 그럼에도 불구 하고, GWI가 2017년 발표한 예측에 따르면, 세계 물시장은 2013년 이후 연 4\%정도씩 지속적으로 성장하여 2020년에는 규모가 8,000 억 달러에 이를 것으로 추산되며, 10 년 후인 2030년에는 11,306억 달러에 이를 것으로 예측되었다(Fig. $1(\mathbf{a}))^{5)}$

세계 물시장을 전체적으로 봤을 때 각 분야에 대한 자본 지 출 비율은 하수관망이 $30 \%$, 관망이 $22 \%$ 로 관망에 대한 투자 가 많이 이루어지고 있으며, 하수처리장 설비 $16 \%$, 정수 설비 $10 \%$ 로 상하수도 시설 설비에 대한 투자가 그 다음으로 많이 이루어지는 것으로 나타났다. 다음으로는 담수화 포함 수자원 관련 투자가 $10 \%$, 산업용수 관련 투자가 $8 \%$, 슬러지 관리를 위한 투자가 $4 \%$ 순으로 나타났다. ${ }^{5)}$ 하지만, 지역에 따라 수요 및 투자 패턴이 다르게 나타날 수 있다. 예를 들면, 유럽과 북미 등 선진국이 다수인 지역에서는 신규 수처리 설비에 대 한 투자보다는 노후화된 관망 교체 등에 대한 수요 및 투자에 대한 비율이 높게 나타난다. 그러나 남미, 아프리카 동남아 등 개발도상국이 다수 포진된 지역에서는 공적개발원조 연계
투자를 통한 신규 수처리 설비 및 관망 설치에 대한 수요 및 투자가 높게 나타난다. 그리고 중동과 같이 사용 가능한 담수 가 절대적으로 부족한 사막 지역에서는 해수담수화에 대한 수요 및 투자가 높게 나타난다.

지역에 의한 차이 이외에도, 기후 환경 변화, 점점 더 엄격해 지는 수질 규제, 과학기술의 고도화는 새로운 분야에 대한 수 요와 투자를 증가시킨다. 예를 들면, 지속가능한 수자원 확보 를 위한 해수담수화, 물재이용과 같은 대체 수자원에 대한 수 요 및 투자 증가, 새로운 수질 규제를 고려한 고도 수처리 시 장의 수요 및 투자 증가, 4 차 산업 혁명의 영향으로 전통적인 수처리 및 물 관리 기술에 인공지능, 사물인터넷, 로봇 등과 같은 첨단 정보통신 기술의 적용을 통한 시스템의 자동화 및 연결성을 극대화시킨 스마트워터 관련 시장의 급격한 성장 등이 있겠다. ${ }^{13)}$

그리고 최근 발생한 세계적 코로나19 대유행은 세계 경제에 타격을 입혔으며, 이는 다양한 산업이 밸류체인을 이루고 있 는 물산업에도 영향을 주었다. 그 결과, 물산업 분야에 대한 신규 투자가 크게 위축되었다. Fig.1(b)에서 볼 수 있듯이, 2020년의 물산업에 대한 자본 투자 전망치는 코로나19 대유 행으로 인해 기존의 발표되었던 전망치보다 약 $8 \%$ 가 하향 조 정되었다. 하지만, 코로나 19 의 대유행은 하수에서의 바이러 스 모니터링 기술, 언택트(untact) 수자원 관리 시스템 등의 새로운 분야에 대한 투자를 촉진시키는 결과를 가져왔다. ${ }^{5)}$ 따라서 향후 물산업은 기본 인프라, 하수관리 등과 같은 기 존의 전통적인 수요 및 투자에 해수담수화와 같은 새로운 수 자원과 스마트솔루션에 대한 수요 및 투자가 빠르게 증가할 것으로 기대된다(Fig. 2(a)와 (b)). ${ }^{14,15)}$

\section{2. 국내 물산업 현황 및 발전 동향}

먼저, 물 관련 인프라 현황을 살펴보면, 상수도와 하수도의 보급률은 2018년 기준 전국 평균 각각 약 $98.2 \%$ 와 $93.9 \%$ 로 거의 완료 상태에 이르렀다. 이는 공공재적 인프라 구축면에

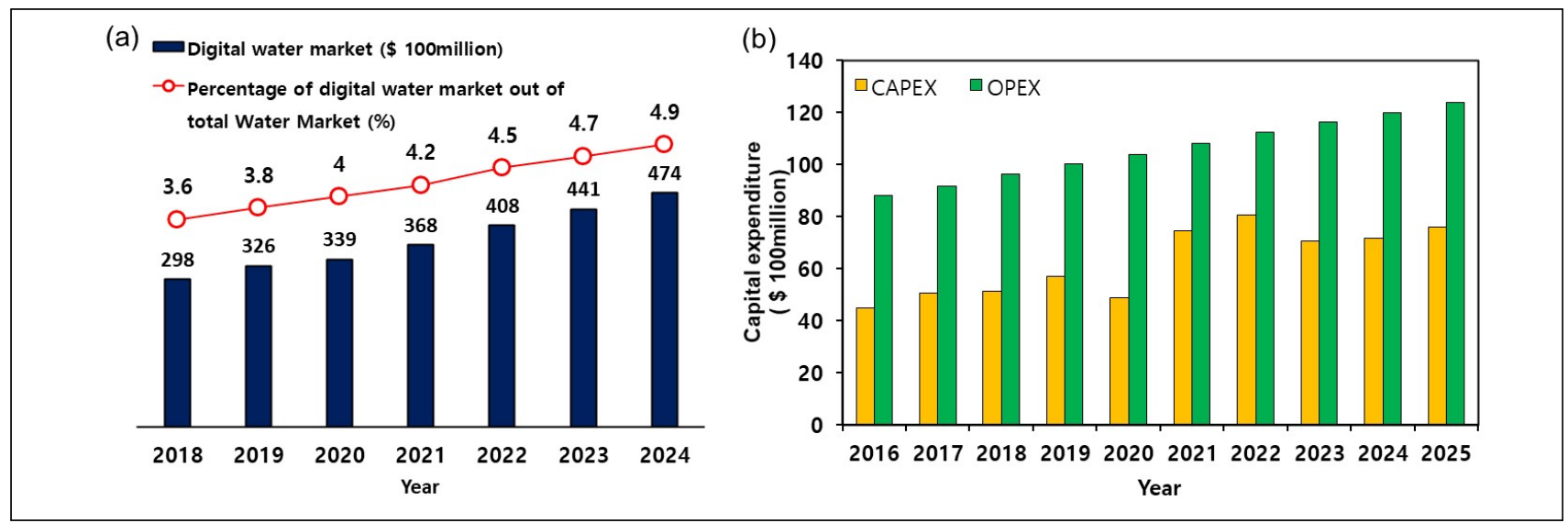

Fig. 2. (a) The scale of the global smart water market (source: water industry trends issued by K-Water) ${ }^{13)}$, (b) capital investment forecast of seawater desalination (source: DesalData). ${ }^{16)}$ 
(a)

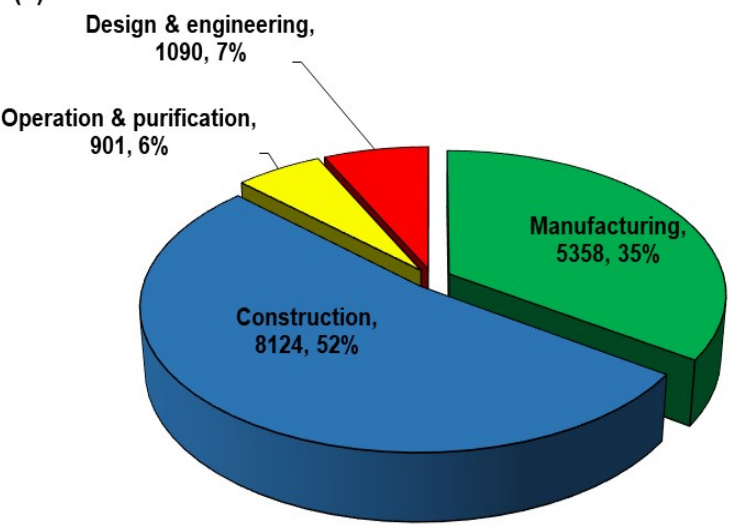

(b)

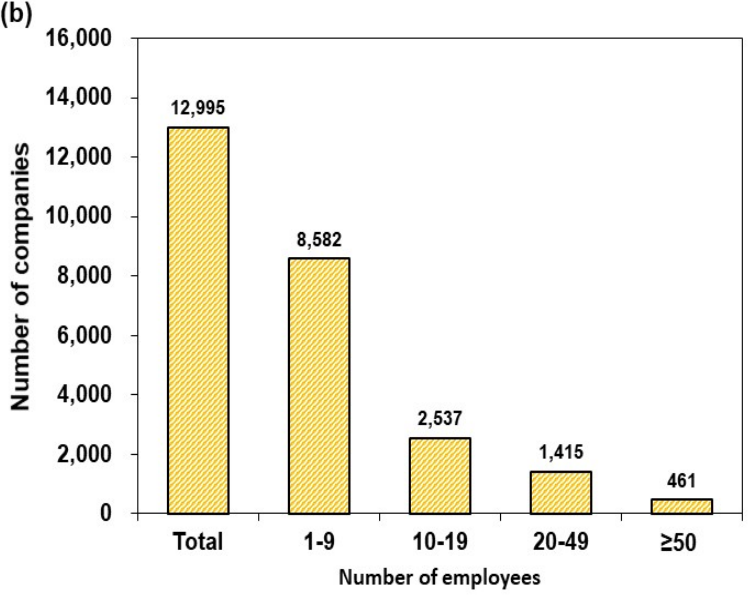

Fig. 3. Status of the domestic water industry-related companies: (a) number of companies by sector, (b) by scale based on the number of employees (source: https://www.watis.or.kr/). ${ }^{19)}$
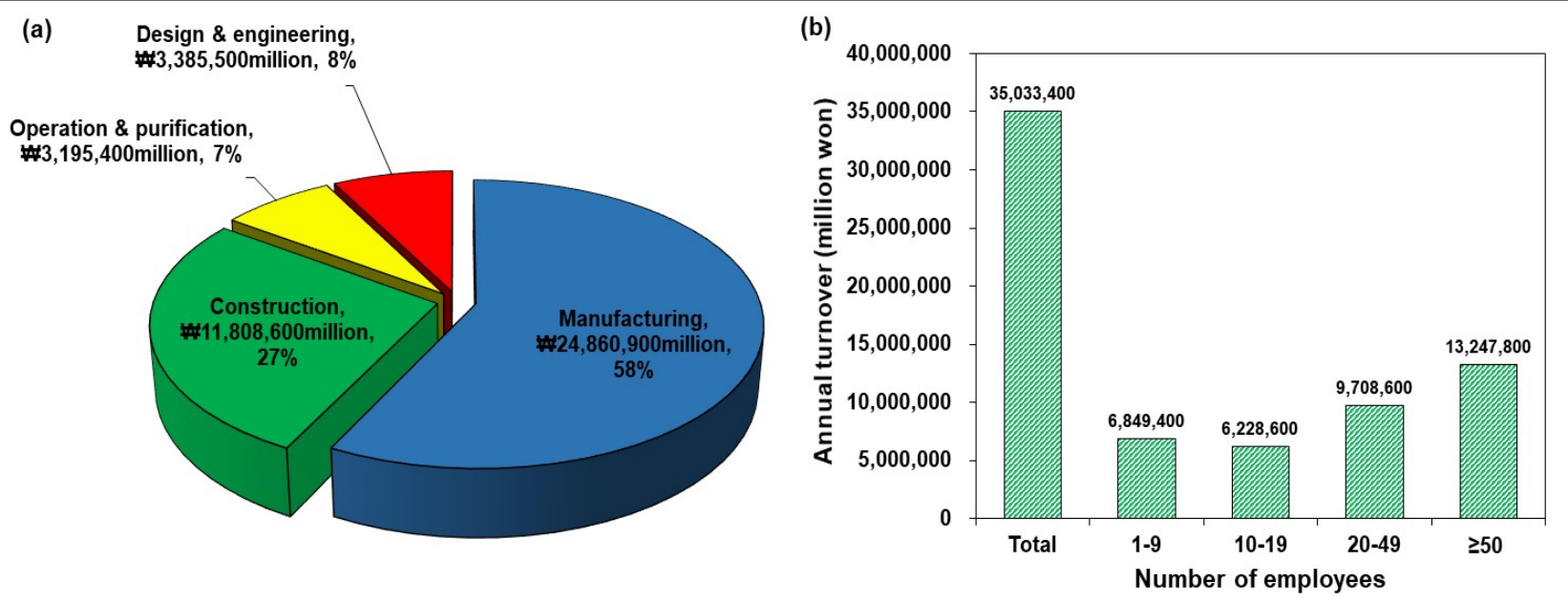

Fig. 4. Status of the domestic water industry-related companies: (a) corporate revenue by sector, (b) by scale based on number of employees (source: https://www.watis.or.kr/). ${ }^{19}$

서는 좋은 일이지만, 국내 물시장의 상당 부분이 상하수도의 시설투자에 의해 발생한 것이라 앞으로는 단순한 상하수도 시설 투자에 의한 물시장의 성장은 더 이상 어렵게 되었다는 것을 말해준다. ${ }^{17-18)}$

다음으로 물산업 관련 기업체 현황에 대해서 살펴보면, 2018 년 기준 총 15,473 개의 물산업 관련 기업이 존재하고 있 으며, 183,793 명이 이들 물산업 관련 기업에 종사하고 있다. 이들 기업체를 업종별로 나누어 보면, 건설업이 $52.5 \%$, 제조 업이 $34.6 \%$, 설계 및 엔지니어링이 $7.0 \%$, 운영 및 정화업이 $5.8 \%$ 로 나타났다(Fig. 3(a)). 다시 이들 기업을 규모에 따라 나누어 보면, 종업원 '9인 이하'의 기업이 약 $69 \%$ 로 가장 높 은 비율을 차지했으며, '10 19인', '20 24인', ‘ 50 인 이상'의 순으로 나타났다(Fig.3(b)). 하지만, 매출은 기업 수와는 조금 다른 양상을 보였다. 전체 매출액 432,505억 원 중(국내 총 생산량(GDP)의 2 3\% 수준), 제조업이 차지하는 비중이 $57 \%$
로 가장 높았고, 건설업 $27 \%$, 설계 및 엔지니어링 $8 \%$, 운영 및 정화업 $7 \%$ 순이었다(Fig. 4(a)). 또한, 기업 규모에 따른 매출액도 ‘50인 이상' 종업원을 가진 규모의 기업에서 가장 높게 나타났으며, '20 49인', '1 9인', '10 19인'의 순서를 보였다(Fig.4(b)). 이는 국내 물산업 관련 기업이 대부분 영 세하다라는 것을 보여주며, 이들 업체들이 차지하는 매출 비 중이 그 수에 비해 크지 않다는 것을 보여준다. 또한, 물산업 에서도 제조업이 차지하는 비중이 상당하다는 것을 보여준 다. 이러한 국내 물산업 기업의 분포 구조는 수출액에서도 그대로 반영되어 나타난다. 총 수출액 19,306억 원은 국내 물산업 관련 기업체의 총매출액의 약 $4.5 \%$ 정도에 불과했으 며, 제조업 편중 현상이 심하게 나타났다(약 87\%)(Fig.5(a)). ${ }^{19)}$

최근 GWI가 발표한 주요국가의 물 분야 경쟁력 평가에서 우리나라의 물 분야 경쟁력은 세계 11 위의 나쁘지 않은 성적 을 거둔 것과는 상당히 대조적으로, 많은 구조적 문제점들을 


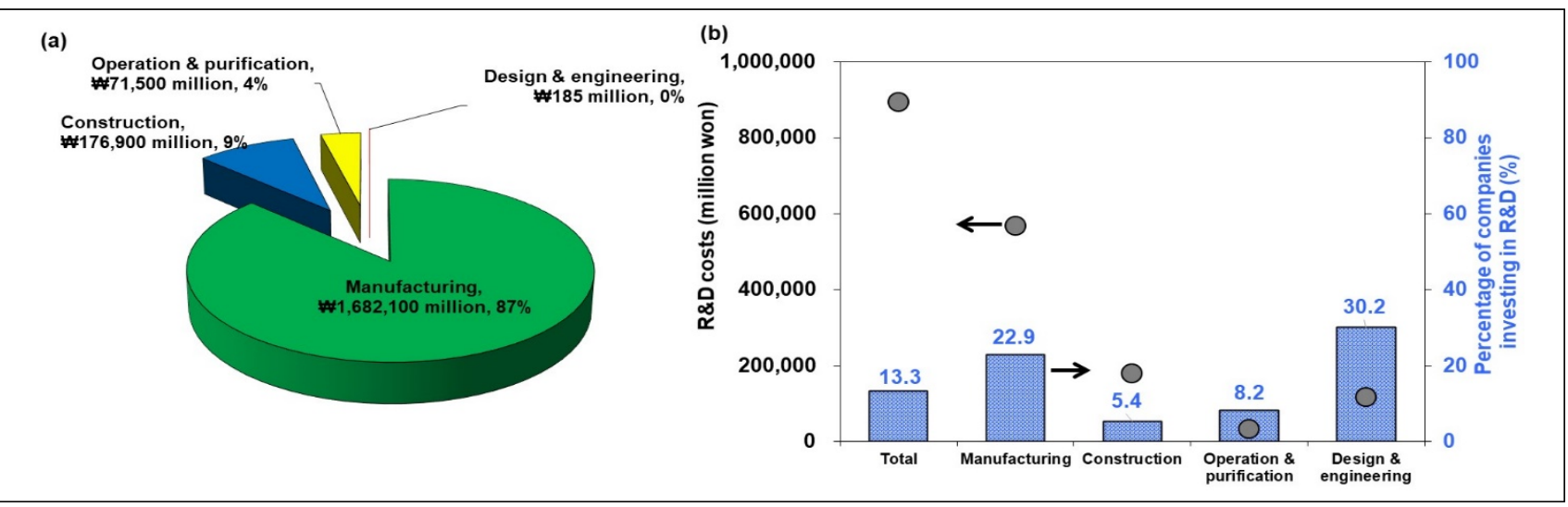

Fig.5. (a) Status of the export amount in the domestic water industry by sector, (b) status of research and development (R\&D) in the domestic water industry: total R\&D investment cost and percentage of companies invested in R\&D by sector (source: https://www.watis.or.kr/). ${ }^{19)}$

안고 있다. 먼저, 물산업 관련 기업 대부분이 종업원 9인 이하 의 영세기업이기 때문에 연구 개발에 대한 투자 여력이 없다. 또한 물산업 총 매출액의 약 $70 \%$ 가 공공 발주에 의한 단순한 시설 투자 위주로 성장해 왔기 때문에 물기업들의 대부분이 기술 경쟁력이 없을 뿐 아니라, 이들 기업의 매출 중 내수시장 이 차지하는 비중이 $95.6 \%$ 로 내수시장에 대한 의존도가 아주 심하다. 일례로 Fig. 5(b)에 나타난 국내 물기업이 연구개발에 투자하는 자본은 매출액의 약 $2.6 \%$ 로 극히 낮은 수준이며, 연구개발에 투자하는 회사의 비율은 전체 $13.3 \%$ 정도에 지나 지 않는다. 이는 국내 물 인프라 시장이 포화상태에 이른 현재 상황에서 물산업의 성장을 기대할 수 없게 할 뿐 아니라, 새로 운 시장을 개척하는데 큰 걸림돌이 될 것이다. ${ }^{13)}$

향후 세계 물산업은 시대적 상황과 맞물려 일정 규모 이상 의 꾸준한 성장세를 보일 것이기에 포화된 내수시장을 넘어 해외 시장 개척을 위해 국내 물산업의 경쟁력을 키우는 것은 반드시 필요하다. 하지만, 국내 물기업은 영세성과, 기술력, 관련 실적(track record) 부족으로 인해 해외 진출에 어려움을 겪고 있다. 이를 해결하기 위해서는 새로운 분야 개척을 통한 국내 물시장의 규모를 확대함으로써 규모의 경제를 달성하는 것이 중요할 것으로 판단된다. 또한, 물시장의 민간에 대한 유연한 개방 및 확장이 필요하며, 국가 차원의 지원을 통해서 민간기업이 새로운 해외 시장을 개척하는 것을 지원할 필요가 있어 보인다. 그리고 향후 성장 잠재력이 높은 대체 수자원과 스마트 물기술에 대한 공격적 투자가 이루어져야 할 것이다.

\section{3. 국내 물산업 발전 육성 정책}

정부 차원에서 본격적으로 물산업 육성을 위한 정책을 추진 한 것은 2006년부터이다(Table 2). ${ }^{20)}$ '2006년 물산업 육성방 안’을 통해서 상하수도 서비스업의 구조개편, 핵심기술 고도 화, 물산업 수출역량 강화의 추진전략을 수립하여 정책을 추 진하였다. ${ }^{21)}$ 2010년에는 ‘물산업 육성전략'을 발표하며 원천 기술 개발, 상하수도 통합 관리를 통한 전문 물기업 육성, 물
연관산업 육성을 추진하였다. 2012년에는 '물산업 육성 및 해 외 진출 활성화 방안'을 시행하며, 핵심 신기술 개발, 물기업 육성, 해외진출 기반 강화와 전략적 진출을 추진하였다. ${ }^{22)}$ 2016년에는 ‘스마트 물산업 육성 전략'을 발표하며, 물기업 기술 경쟁력 강화, 물재이용, 스마트워터, 대체 수자원 등의 신시장 창출, 물산업혁신기반 조성을 달성하기 위한 12 개의 중점 과제를 추진하였다.

하지만, 국내 물산업 현황에서 보았듯이 지금까지의 물산 업 육성 정책은 크게 실효성 있는 성과를 내는데 실패하였 다. 그 원인으로 계획의 구체적인 실행 부족, 산발적인 지원 프로그램 운영, 분산된 물관리로 인한 부처 간의 인식차이, 내수시장의 규모의 경제 달성 실패 등이 꼽히고 있다. ${ }^{23)}$ 그러 나 2018 2019년 이른바 ‘물관리 일원화 3법'이 통과되면서 물산업 육성을 위한 보다 실효성 있는 조치들이 이루어지기 시작했다. 먼저, 국토부의 수자원 관리 업무가 환경부로 이관 되면서 물관리 체계가 일원화되었고, 대통령 직속 국가물관리 위원회가 출범함에 따라 보다 효율적이고 통합적인 물관리 정책 시행이 기능해졌다. 또한, 국가물산업클러스터의 조성을 통해 물기업에 대한 보다 실질적인 기술개발과 해외진출 지원 이 이루어질 수 있는 기반이 마련되었다. 이러한 기반을 바탕 으로 2019년에는 '제1차 물관리기술 발전 및 물산업 진흥기본 계획'을 발표하였고, 2030년까지 '기술 선도형 강소기업 30개 육성', ‘물산업 매출액 50조원 달성', ‘해외수출 10 조원 달성', ‘물산업 일자리 20 만개 육성'의 목표를 달성하기 위한, 구체적 인 전략 과제들이 시행되고 있다(Table3). 이와 함께 각 지자 체도 지역 특성에 맞는 지역 물산업을 육성하기 위한 조례를 제정하고, 이를 바탕으로 정책을 시행해 나가고 있다. ${ }^{24)}$ 대표 적인 예가 경기도의 2019년 제 2 차 경기도 물산업 육성 5 개년 종합계획 수립 및 시행을 통한 지역 기업 지원, 대구 국가물산 업클러스터를 중심으로 한 물산업 발전 계획 수립 및 시행, 부산의 해수담수화 집중 육성, 제주도의 용암수를 활용한 물 산업 집중 육성 등이다. ${ }^{14,22,23)}$ 
Table 2. Policies for development of water industry pursued by the Korean government before $2019 .^{21)}$

\begin{tabular}{|c|c|c|}
\hline Year & Policies for development of water industry & Contents \\
\hline 2006 & $\begin{array}{l}\text { Strategies on the promotion of the water industry } \\
\text { (물산업 육성 방안) }\end{array}$ & $\begin{array}{l}\text { Restructuring the water and sewage service industry, advancing core } \\
\text { technologies, and strengthening the export capacity of the water } \\
\text { industry }\end{array}$ \\
\hline 2010 & $\begin{array}{l}\text { Strategies for fostering the water industry } \\
\text { (물산업 육성 전략) }\end{array}$ & $\begin{array}{l}\text { Securing source technologies, fostering specialized water companies for } \\
\text { integrated water and sewage management, and promoting } \\
\text { water-related industry }\end{array}$ \\
\hline 2012 & $\begin{array}{l}\text { Strategies for developing the water industry and promoting } \\
\text { overseas expansion } \\
\text { (물산업 육성 및 해외 진출 활성화 방안) }\end{array}$ & $\begin{array}{l}\text { Developing new core technologies, fostering water companies, } \\
\text { strengthening the foundation of overseas expansion, and conducting } \\
\text { strategical overseas expansion }\end{array}$ \\
\hline 2016 & $\begin{array}{l}\text { Strategies for promoting the smart water industry } \\
\text { (스마트 물산업 육성) 전략) }\end{array}$ & $\begin{array}{l}\text { Enhancing technological competitiveness of water companies, and } \\
\text { developing new market related to water reuse, smart water, and } \\
\text { alternative water resources }\end{array}$ \\
\hline
\end{tabular}

Table 3. Summary of the 1st primary plan for water management technology development and water industry development issued by the Korean government in 2019. ${ }^{21}$

\begin{tabular}{|c|c|c|}
\hline Vision and strategic objectives & 4 major strategic challenges & 12 detailed tasks \\
\hline \multirow{12}{*}{$\begin{array}{l}\text { Jumping up to the level of an } \\
\text { advanced country in the water } \\
\text { industry by securing } \\
\text { technologies for sustainable } \\
\text { water management }\end{array}$} & \multirow{3}{*}{$\begin{array}{l}\text { Reinforcing innovative capacity for } \\
\text { water management technologies }\end{array}$} & - Securing technologies for sustainable water management \\
\hline & & - Obtaining track records and verifying innovative technologies \\
\hline & & $\begin{array}{l}\text { - Commercializing excellent products and promoting the distribution of } \\
\text { the products }\end{array}$ \\
\hline & \multirow{3}{*}{$\begin{array}{l}\text { Expansion of new markets and } \\
\text { revitalization of overseas expansion }\end{array}$} & - Promoting convergence industry with water industry \\
\hline & & $\begin{array}{l}\text { - Addressing barriers to entry into overseas markets for water } \\
\text { industry-related companies }\end{array}$ \\
\hline & & • Establishment and utilization of global network \\
\hline & \multirow{3}{*}{$\begin{array}{l}\text { Creating jobs and raising } \\
\text { professionals for water } \\
\text { management }\end{array}$} & - Training field-oriented and customized manpower \\
\hline & & - Utilization and management of human resources in the water industry \\
\hline & & - Creating an innovative startup ecosystem in the water industry \\
\hline & \multirow{3}{*}{$\begin{array}{l}\text { Development of a strategic system } \\
\text { for promoting the water industry }\end{array}$} & - Improving laws/systems /infrastructure related to water industry \\
\hline & & - Developing a water industry cluster as the water industry hub \\
\hline & & - Strengthening cooperation and communication \\
\hline
\end{tabular}

\section{4. 경상남도 물산업 관련 인프라 및 기업 현황}

다음은 경상남도의 지역 물산업 현황에 대해서 살펴보고자 한다. 경상남도는 8 개 시와 10 개 군의 행정구역으로 이루어져 있고, 인구는 약 330 만 명이다. 상수도와 하수도 보급률은 각 각 $94.4 \%$ 와 $91.0 \%$ 로 전국평균인 $98.2 \%$ 와 $93.9 \%$ 보다 낮은 편이다(Fig.6). 군 단위 지자체의 상하수도 보급률이 낮기 때 문으로 도서산간 지역이 포함되어 있는 지역적인 한계에 의한 것이다. 이러한 상황을 고려한다면 경상남도의 상하수도 보급 은 거의 완료된 상태라 할 수 있겠다.

물산업과 관련된 인력양성기관인 대학교는 경상대학교, 경 남과학기술대학교, 창원대학교, 경남대학교, 인제대학교 등이 있어 교육기관 인프라는 비교적 잘 갖춰져 있다고 판단된다. 하지만 물산업 관련 연구를 주로 하는 정부 출연 연구기관은 전무하고, 그나마 물산업과 관련된 연구를 조금이나마 수행하 는 기관은 한국재료연구원, 한국산업기술시험원, 한국해양과 학기술원 남해연구소 정도이다. 그리고 물산업 관련 연구기관
과 인력 양성 기관을 효과적으로 연계시키면서 기술 정보를 제공하는 시스템 또한 없는 것으로 파악되었다.

다음으로 경상남도의 물산업 관련 기업에 대해서 살펴보면, 경상남도에는 약 1,368 개 물산업 관련 기업이 있으며, 이들 물산업 관련 기업에 약 34,774 명 정도가 종사하고 있는 것으 로 조사 결과 밝혀졌다. 물기업수로만 보면 경상남도에는 경 기와 서울 다음으로 많은 물기업이 있는 것으로 파악되었다 (Fig.7(a)). 업종별로는 건설업이 강세였으며, 다음으로는 제 조업, 운영 및 정화업, 건설업, 설계 및 엔지니어링 서비스 순 으로 나타났다(Fig.7(a)). 물산업 관련 기업의 규모를 살펴보 면, 국내 전체 물산업의 사정과 비슷하게 기업 수는 종사자수 가 '9인 이하'의 비율이 전체 기업의 $60 \%$ 가 넘을 정도로 높았 으며, '50인 이상'의 종사자를 가지고 있는 규모의 기업은 약 $6 \%$ 정도에 불과한 것으로 파악되었다(Fig.7(b)). 이는 경상남 도의 물산업 관련 기업의 상당 부분이 영세하다라는 것을 보 여주고 있다. 


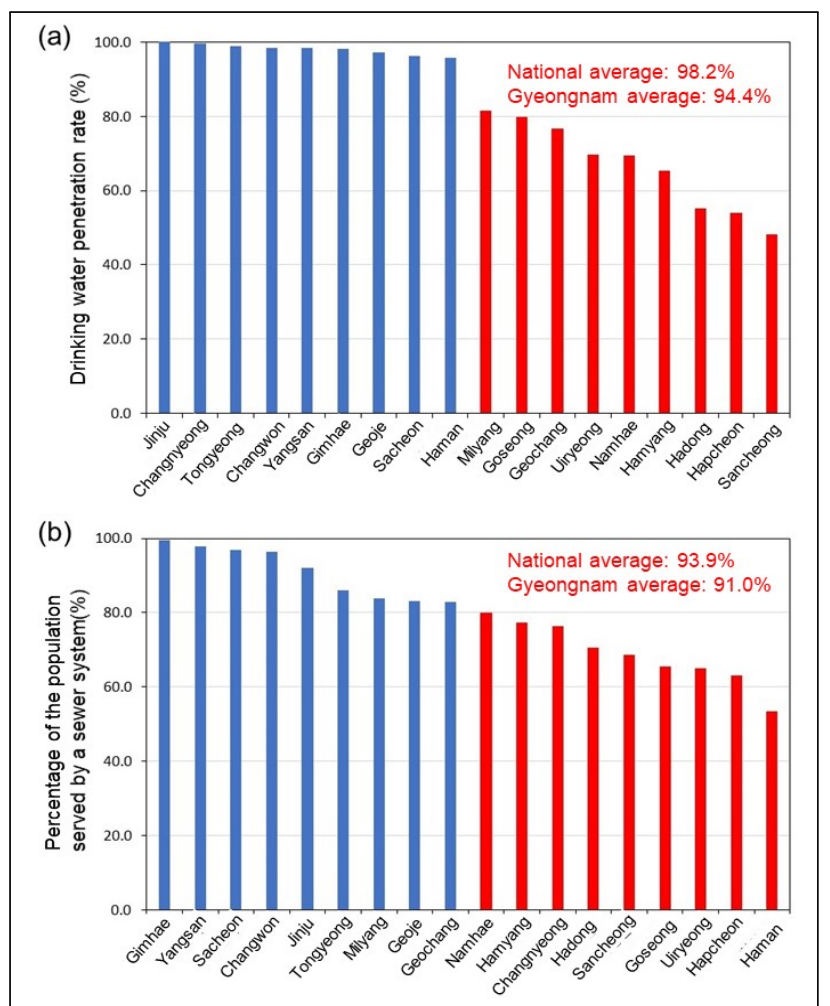

Fig.6. Status of infrastructure related to the water industry in Gyeongsangnam-do: (a) water supply rate, (b) sewage supply rate (source: the basic statistics of Gyeongsangnam-do Province). ${ }^{24}$

경상남도의 물산업 관련 기업의 영세성은 연구개발 활동과 관련된 특허보유건수에서도 잘 나타난다. Fig. 8(a)는 물산업 관련 키워드('상수', ‘하수’, ‘폐수’, ‘물재이용', ‘담수화', ‘수 처리')로 검색한 각 시도의 물산업 관련 특허 보유 건수를 조 사한 그래프이다. 경기도와 서울 다음으로 많은 물기업을 보 유하고 있지만, 연구개발의 산물인 특허건수는 대전, 경상북 도, 충청남도, 인천보다도 낮았다. 또한 경상남도 내 물산업 관련 기업의 $13 \%$ 만이 특허를 보유하고 있었으며, $87 \%$ 의 기 업은 특허를 1 건도 보유하고 있지 않았다(Fig.8(b)). 이는 경
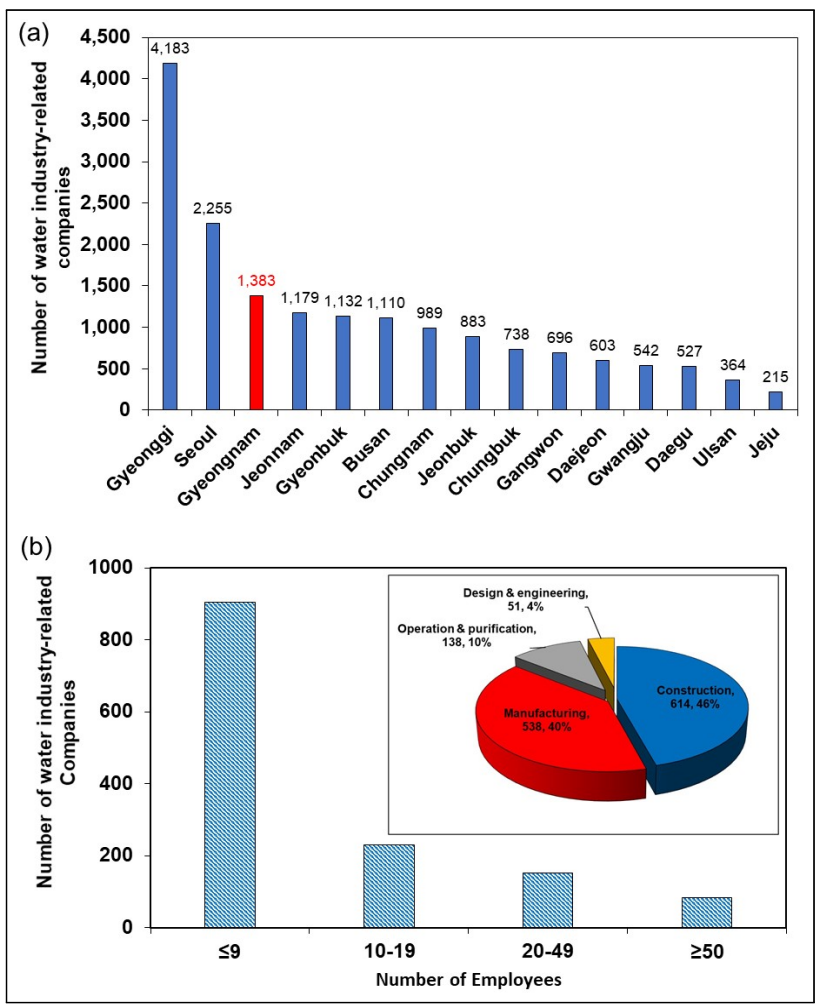

Fig. 7. (a) Number of the water industry-related companies by region in Korea, (b) number of the local water industry-related companies in Gyeongsangnam-do by scale based on the number of employees (from a survey using K-water water industry platform). ${ }^{11)}$

상남도의 대부분의 기업이 연구개발에 투자하지 않는 다는 것을 간접적으로 보여주고 있다. 또한 설문조사에 따르면 경 상남도 내 물산업 기업 대부분이 수출보다는 내수 시장을 통 해 주로 매출을 발생시키고 있었으며, 향후 해외시장에 진출 할 계획이 없는 것으로 파악되었다. 이는 국내 전체 물산업과 상황이 크게 다르지 않았다.

그렇다면 경상남도 내 물산업 관련 기업들이 겪고 있는 주 요 애로사항은 어떤 부분이 있을까? Fig.9는 경상남도 내 물
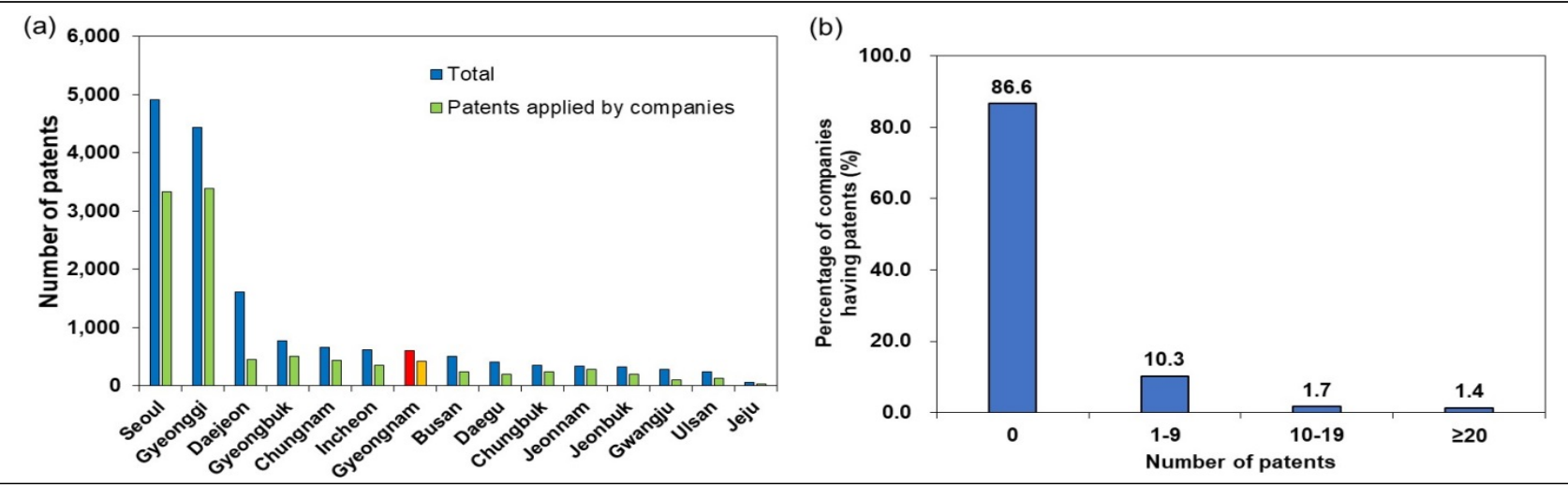

Fig. 8. (a) Number of patents related to the water industry by region, (b) distribution of the water industry-related companies based on the number of holding patents (from a survey using Wips-on database). 


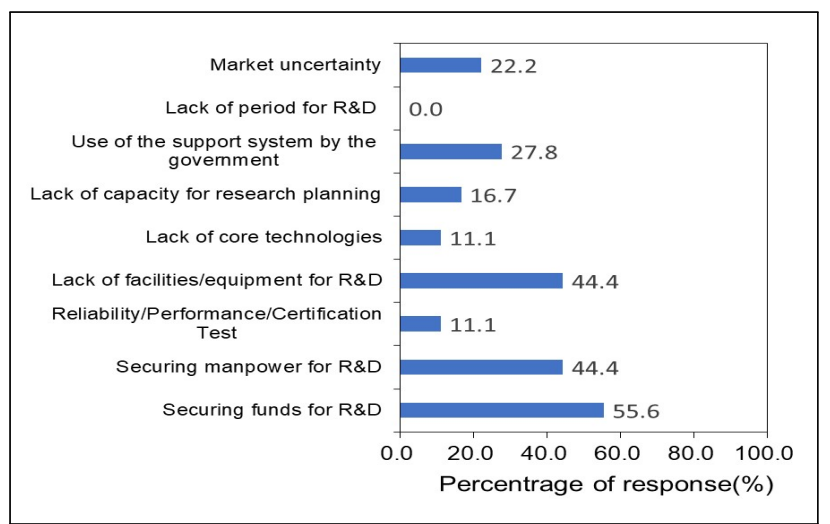

Fig. 9. Difficulties of the water industry-related companies in Gyeongsangnam-do.

산업 관련 기업들이 설문조사 시 응답한 애로사항의 결과를 나타낸 그래프이다. 응답 비율이 가장 높은 애로사항으로는 연구 개발 자금 확보로 나타났으며, 이와 함께 연구개발에 필 요한 인력과 설비/장비 부족이 그 다음으로 응답 비율이 높았 다. 이외에도 정부지원제도 활용의 어려움, 시장의 불확실성, 연구 기획력 부족, 핵심기술력 부족, 신뢰성/성능/인증시험 통 과에 대한 애로사항을 겪는 것으로 나타났다. 이는 도내 물산 업 기업 분포 구조에서 나타났듯이 대부분의 기업이 영세하기 때문에 기업 자체적으로 연구 개발 등을 위한 재원 및 인력확 보 문제를 기업 스스로 해결할 능력이 다소 부족하여 겪는 애로사항이 대부분이었다.

위 애로사항은 Fig. 10에서 볼 수 있듯이 연구개발 인력 지 원, 정부연구과제 수주 지원, 시장정보 마케팅 부분 등 재정 및 인력 확보와 관련된 부분에 대해 지원을 원하는 응답이 높게 나타난 것과 잘 부합한다. 따라서, 이들 업체가 인력과 자본 확보가 보다 원활할 수 있도록 지원하는 한편 기술 개발 을 유도하고 연구기관과의 연계를 통한 연구개발 인력 및 시 설 부족에 대한 어려움을 최소화해 줄 수 있는 정책이 필요하 다. 그리고 지원정책을 통해 가시적인 성과를 얻은 기업들을 선별하고 추가 지원하여 선별된 기업들이 기술을 지속적으로 업그레이드시키도록 하고 수요처를 다변화할 수 있도록 유도 하는 정책 역시 필요하다.

결론적으로, 경상남도는 물산업 관련 인프라는 도서산간 지 역이 많은 지리적 특수성을 감안하면 정비가 잘되어 있고, 물 기업 관련 양적인 지표도 타 시도에 비해 좋은 것으로 판단된 다. 하지만 향후 지역 물산업 발전에 핵심적인 부분을 차지할 기술력과 시장개척 능력을 가진 기업 보유 및 물산업 관련 기관을 효율적으로 연계하고, 지원할 수 있는 질적인 소프트 파워를 향상시킬 필요가 있다. 따라서, 경상남도의 물산업을 질적으로 발전시키기 위한 전략 수립이 필요하다.

\section{5. 경상남도 물산업 발전 방안 및 이를 위한 정책 제언}

앞서 언급했듯이 현재 경상남도는 물산업에 대한 물리적인

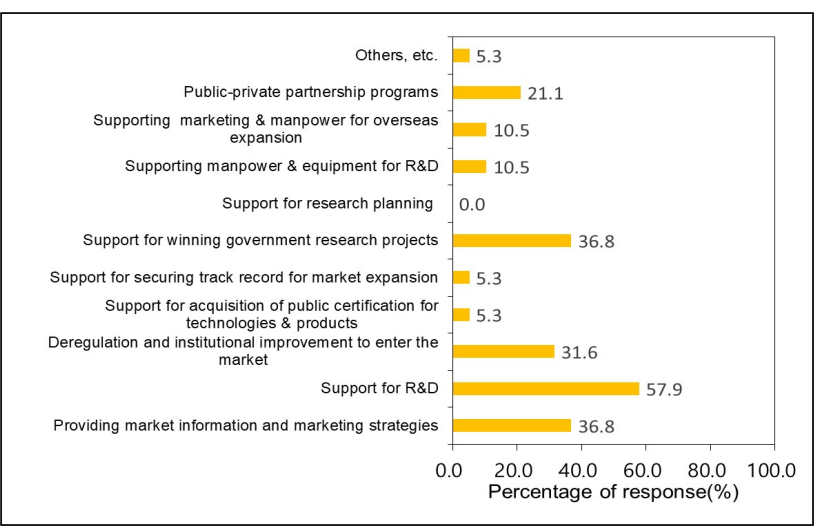

Fig. 10. Areas that require support for the water industry-related companies in Gyeongsangnam-do.

여건은 비교적 충분한 것으로 판단되나 질적인 소프트 파워가 부족하다. 이를 구체화시켜보면 다음과 같은 문제점들로 세분 화된다: 1) 물산업 육성을 위한 제도적 법제화 미흡과 관련 기업 지원을 위한 정책 및 지원기관의 부재, 2) 물산업 관련 정확한 통계 부족 및 물 관련 기업 지원을 위한 인력 및 재원 부족, 3) 물산업 관련 기업의 영세성 및 기술 경쟁력, 4) 물산 업 관련 공공기관 부재 및 물산업 관련 인력양성기관-연구기 관-기업-지방 정부 간 협력 체계 부재, 5) 도내 시설투자에 대 한 신규 수요 감소 및 코로나19 유행으로 인한 내수시장 둔화.

하지만, 이에 못지 않게 물산업 육성을 위해 활용 가능한 다음과 같은 장점 역시 가지고 있다: 1) 우수한 제조업 기반의 산업 인프라, 2) 물산업과 연계 및 발전 가능한 기반 산업 보 유, 3) 다량의 물을 소비하는 수요처 존재, 4) 지리산 지역의 청정 수원지 보유, 5) 동남아 등 신흥 해외 시장 진출에 유리한 지리적 여건.

그렇다면 위에 언급된 문제점을 극복하면서 지니고 있는 장 점을 활용할 수 있는 물산업 육성 전략은 무엇이 있을까?(Fig. 11) 첫째, 물산업 육성을 위한 환경조성이 필요하다. 먼저, 물 산업 육성을 위한 중장기 사업 추진을 위한 기초 연구가 선행 되어야 한다. 그리고 이를 통해 도출된 결과를 바탕으로 적절 한 지원 전략 및 제도의 마련과 법제화를 통한 물산업에 대한 지원 근거를 마련할 필요가 있다. 또한 지역 물산업 관련 기업 을 종합적으로 지원할 수 있는 체계를 마련하여야 한다. 경상 남도 내 물산업에서 대부분을 차지하는 중소기업은 기술력, 네트워크, 해외진출실적, 마케팅 능력 등의 역량 부족으로 인 한 어려움이 큰 것으로 나타났다. 따라서, 기술 개발, 마케팅, 해외진출, 인력 지원, 재정 등을 기업 및 창업에 통합적으로 지원할 수 있는 오픈 플랫폼 구축 및 이를 전담하는 기구의 설치가 절실하다.

둘째, 국내외 네트워크 강화가 필요하다. 국내 네트워크 강 화를 위해서는 향후 진행될 공공기관 지방이전을 통한 환경산 업기술원과 같은 물산업 관련 공공기관의 유치 및 인근 지자 체인 대구(국가물산업클러스터)와 부산(해수담수화)과의 협 


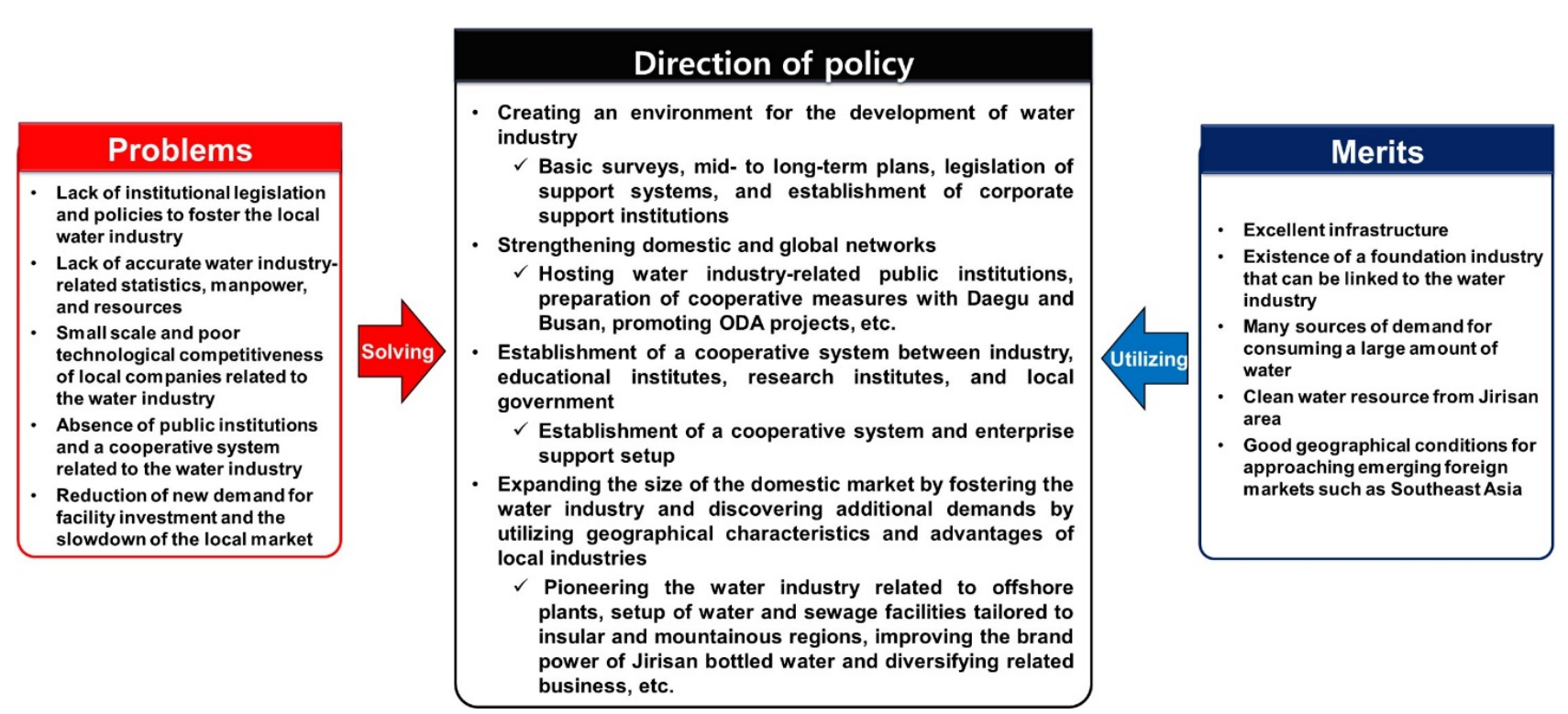

Fig. 11. Strategies for developing the local water industry in Gyeongsangnam-do.

력방안 등을 적극적으로 고려해야 한다. 기존 지방 이전 공공 기관의 사례를 보면 관련 산업 및 연구개발 네트워크 안에서 허브역할을 잘 수행하고 있는 것으로 나타났고, 지역 기관 및 기업의 네트워크 참여 비중이 향상되었다. ${ }^{25)}$ 따라서, 물산업 정책 및 연구 과제 기획 관련 공공기관의 경상남도 이전은 물산업 관련 기업 및 연구소 유치와 산-학-연-관 협력 체계 구축 및 지식 정보 교류 등 지역 물산업 발전의 혁신 창출에 기여할 수 있을 것으로 판단된다. 또한, 인근 지자체인 대구 및 부산과의 협력 체계를 구축하게 되면 각 지자체에서 보유 한 다양한 물 기술 개발 인프라(국가물산업클러스터 및 해수 담수화 테스트베드)를 통해 지역 물산업 관련 기업의 기술 혁 신에 도움을 줄 수 있을 것으로 기대된다.

해외 네트워크 구축도 향후 경상남도 내 물기업의 해외 진 출을 지원하고, 물산업 관련 글로벌 기업의 유치를 위해서 반드시 필요하다. 이를 위해서는 국제개발협력을 통한 해외 수요처 확보 ${ }^{26)}$, 해외 잠재 수요 도시와의 자매결연을 통한 네트워크 확보 및 물 인프라 개선 공동 프로젝트 추진, 해외 시장 정보를 수집하고 공유할 수 있는 플랫폼을 구축하여야 한다.

셋째, 지역의 기업, 연구기관, 인력양성기관, 정부간 원활한 소통이 가능한 협력 체계 구축이 필요하다. 경상남도 내의 물 산업 관련 기업의 애로사항 중 기술개발 및 인력지원, 정부연 구과제 수주지원, 연구개발/장비 인력지원, 민관협력프로그램 가동 등의 문제는 대부분 산-학-연-관의 원활한 협력을 통해 서 해결될 수 있다. 물산업 기술개발은 상당히 긴 연구기간과 막대한 자금이 필요하고, 물기술의 특성상 ET, BT, NT, IT등 여러 기술이 융합된 특성을 갖는다. 또한 전세계적으로 자본 투자의 트렌드가 공정 기술보다는 운영관리 기술로 변화하면 서 ICT 기술이 접목되는 추세이다. ${ }^{27)}$ 이러한 산업적 특성과
추세에 대응하기 위해서는 각 분야 및 기관 간 유기적인 협력 체계가 반드시 필요한데, 현재 경상남도는 이러한 역할을 수 행할 물산업 관련 산-학-연-관 협력체계가 없다. 그러므로 방 위산업혁신클러스터 등 다른 산업분야의 사례를 벤치마킹하 여 실효성 있는 협력체계를 구축할 필요가 있다.

마지막으로 경상남도의 지리적 특성과 산업적 장점을 활용 한 물산업 육성 및 추가 수요 발굴을 통한 내수시장 규모의 확대가 필요하다. 먼저, 지리산 청정수원의 먹는 샘물 브랜드 강화 및 이를 활용한 사업 확장을 고려해 볼 수 있겠다. 제주 도의 경우, 용암수를 이용한 지역 물산업 육성에 집중적으로 투자를 한 결과, 현재 제주삼다수는 2019년 기준 국내 먹는 샘물 시장의 약 $40.2 \%$ 를 차지하고 있다. ${ }^{28)}$ 또한, 용암해수산 업화지원센터를 설치하여 용암수를 활용한 다양한 기능성 상 품 출시를 지원하고 있다. ${ }^{29)}$ 경상남도의 지리산수의 경우, 2019년 물의 날에 개최된 제4회 먹는샘물-정수기 품평회에서 광천수 부문에서 1 위를 차지할 정도로 상품성을 인정받았 다. ${ }^{30)}$ 하지만, 아직도 지리산수를 수원으로 사용하는 먹는샘 물의 인지도는 낮은 편으로 브랜드화 전략을 강화할 필요가 있다. 그리고 지리산의 청정수원을 이용한 기능성 음료 및 화 장품등의 제품 개발, 청정수원을 이용한 무공해 식재료 생산 사업 등의 발전 전략을 고려해야 한다.

또한 지역 핵심 제조 산업인 해양플랜트 산업과 연관된 물 산업 분야인 선박평형수 검사 기관 및 관련 기업의 유치 추 진을 고려해 볼 수 있겠다. 그리고 '스마트시티 통합 플랫폼 기반 구축사업', ‘희유금속산업클러스터 조성 사업', ‘노후 상하수도 시스템 고도화' 와 같이 현재 경상남도의 추진(예 정) 사업들과 연계하여 물산업 분야를 육성할 필요가 있다. 이를 통해 사업간 시너지효과와 지역 물산업 관련 기업체의 참여기회 확대를 통한 지역 내수시장의 활성화를 기대할 수 
있겠다.

\section{4. 결론}

거대한 성장 잠재력을 지닌 세계 물시장 선점을 통해 새로 운 성장동력을 확보하고자 정부는 제 1 차 물관리 기술 발전 및 물산업 진흥 기본계획을 수립하고 관련 법령을 제정해 국 내 물산업 육성을 본격적으로 추진하고 있다. 이와 함께 물산 업 육성을 위한 각 지자체의 역할도 확대되어 지자체의 특성 을 고려한 지역 물산업 진흥을 위한 노력이 요구되고 있다. 따라서, 본 기술자료에서는 경상남도의 물산업 현황 및 육성 방안에 대해서 살펴보았다. 경상남도의 지역 물산업은 수익 창출 구조의 단순화와 물산업 관련 기업의 영세성 등의 문제 점이 있는 것으로 나타났다. 그러나 그 어느 때 보다도 국가적 으로 물산업 육성을 위한 실효성 있는 노력이 계속되고 있는 상황에서 경상남도가 도내 물산업 현황과 산업적 특성을 고려 한 지원 전략을 수립하고, 적극적으로 이를 정책에 반영하고 실천한다면 물산업은 향후 경상남도의 새로운 성장동력의 하 나가 될 수 있을 것이다.

\section{Acknowledgement}

이 논문은 2020년도 경남녹색환경지원센터의 연구사업비 를 지원받아 연구되었습니다(20-11-1-80-81).

\section{References}

1. S. R. Carpenter, E. H. Stanley, M. J. V. Zanden, State of the world's freshwater ecosystems: physical, chemical, and biological changes, Annu. Rev. Environ. Resour., 36, 75-99 (2011).

2. A. E. Eissa, M. M. Zaki, The impact of global climatic changes on the aquatic environment, Procedia Environ. Sci., 4, 251-259(2011).

3. UNESCO, United nations world water development report 2020: water and climate change, UNESCO, Paris, France, pp. 32(2020).

4. S. Kim, S. Jang, J. Suh, H. Choi, Global Water Market Outlook, in Proceedings of the Korea Water Resources Association Conference, KWRA, Jeju, Korea, pp. 73-73 (2020).

5. Global Water Intelligence, Global Water Market, Oxford, United Kingdom(2017).

6. B. W. Kim, Y. K. Koh, D. H. Choi, D. G. Kim, G. B. Kim, Current states of the global water market and considerations for the groundwater industry in South Korea, J. Eng. Geol., 24(3), 431-440(2014).

7. H.-S. Kim, Development of oversea markets and job creation in water industry in environmental sector, Water for Future, 51(1), 24-28,(2018).
8. Y. I. Kim, Y. J. Kim, The development of water management technology and the establishment of implementation plans for the development of water industry, in Proceeding of Chungnam Institute Seminar, Chungnam Institute, Chungnam , Korea(2019).

9. M. K, Kim, Status analysis and activation plan for the water industry in Chungcheongbuk-do province, Chungbuk FOCUS, 4, 1-26(2020).

10. Y. M. Cho, Y. S. Hong, The strategies for activating private participation in the sector of water industry operation management, Gyeonggi Research Institute, Suwon, Korea, pp. 1-155(2017).

11. K-Water, https://www.kwater.or.kr/, $\operatorname{March}(2021)$.

12. OECD, OECD environmental outlook to 2050: The consequences of inaction, OECD Publishing, pp. 1-353, Paris, France(2012).

13. K-Water Institute, Water industry trends: Understanding the water industry and prospects for the digital water industry, K-Water Institute, Daejeon, Republic of Korea(2020).

14. Gyeonggi Privionce Water Industry Support Center, The 2nd 5-year comprehensive plan for water industry development in Gyeonggi-do province (2020 2024), Gyoenggi Privionce Water Industry Support Center, Yongin, Korea(2020).

15. C. Choi, C.-M. Kim, J. Kim, D. Kim, I. S. Kim, Econimic assessment based on energy consumption on the capacities in seawater reverse osmosis (SWRO) plant in Korea, J. Korean Soc. Environ. Eng., 41(7), 389-398(2019).

16. GWI DesalData Home Page, https://www.desaldata.com, December(2020).

17. Ministry of Environment Home Page, https://www.waternow. go.kr/web/ssdoData?pMENUID=8, December(2020).

18. Ministry of Environment Home Page, http://www.me.go.kr/ home/web/board/read.do?menuId=286\&boardMasterId=1\& boardCategoryId=39\&boardId=1160050, December(2019).

19. Ministry of Environment, https://www.watis.or.kr/web/user/ main.do, April(2020).

20. H.-S. Kim, Forstering program of water industry and private operation of waterworks, J. orean Soc. Environ. Eng. 20(12), 1291-1296(2007).

21. Ministry of Environment, https://www.me.go.kr/home/web/bo ard/read.do?boardMasterId=39\&boardId=1033430\&menuId= 290, September(2019).

22. S. C. Han, A strategy on the establishment of the research foundation for the development of the water industry in Jeju, Jeju Research Institute, Jeju, Korea(2017).

23. S. G. Shin, Specialization strategies of the water industry in Busan metropolitan city, Busan Research Institute, Busan, Korea(2018).

24. Gyeongsangnamdo Bigdata Hompage, https://www.gyeongnam. go.kr/data/, December(2020).

25. W. H. Lee, T. U. Ha, H. M. Choi, J. W. Lee, G. J. Cho, S. D. Kim, M. K. Song, Analyzing the effectiveness of local relocation of public institutions in Korea, Korea Institute of Public Finance, Sejong, Korea(2015).

26. H. S. Kim, Strategy for global environmental market entry 
of domestic environment industry using international financing instrucment and domestic ODA, J. Korean Soc. Environ. Eng. 41(10), 590-596(2019).

27. D. Lee, S. Lee, D. Lee, J. Park, Analysis of research trends based on text mining in the Journal of Korean Society of Environmental Engineering, J. Korean Soc. Environ. Eng. 43(2), 101-109(2021).

28. Maeil Businees News Korea Home Page, https://www.mk. co.kr/news/business/view/2019/03/194552/, March(2019).

29. Lava Seawater Industrialization Support Center Home Page, http://www.jejulavawater.com/en/complex/intro.do, December (2020).

30. Maeil Ilbo Home Page, https://www.m-i.kr/news/articleView. html?idxno=506287, $\operatorname{March}(2019)$.

\section{Declaration of Competing Interest}

The authors declare that they have no known competing financial interests or personal relationships that could have appeared to influence the work reported in this paper.

\section{Authors and Contribution Statement}

\section{Euntae Yang}

Department of Marine Environmental Engineering, Gyeongsang Nation University, Assistant Professor, ORCID (ㄷ) 0000-0001-5139 -9910: Conceptualization, Methodology, Funding acquisition, Supervision, Visualization, Writing - review and editing, Validation, Writing - original draft.

\section{Hyang-Mi Kim}

Department of Marine Environmental Engineering, Gyeongsang Nation University, Researcher, ORCID (C) 0000-0002-6420-506X: Methodology, Validation, Writing - original draft, Writing - review and editing.

\section{Ho Bin Jee}

Department of Marine Environmental Engineering, Gyeongsang Nation University, Master Student, ORCID (1) 0000-0002-1405-913X: Data curation, Writing - original draft, Writing - review and editing.

\section{Seung Hyun Song}

Department of Marine Environmental Engineering, Gyeongsang Nation University, Bachelor Student, ORCID 다 0000-0002-28888764: Data curation, Writing - original draft, Writing - review and editing.

\section{Changkyoo Choi}

Water Convergence Research Team, Korea Water Cluster, Korea Environment Corporation (K-ECO), Manager, ORCiD (1) 0000-0003 -3217-2408: Conceptualization, Validation, Writing - reveiw and editing. 